\title{
Principal leaders in the central government since the 1982 constitution
}

President (国家主席)

Li Xiannian (李先念) 18 June 1983-8 April 1988

Yang Shangkun (楊尚昆) 8 April 1988-27 March 1993

Jiang Zemin (江澤民) 27 March 1993-23 March 2003

Hu Jintao (胡錦濤) 23 March 2003-(incumbent)

Premier (中华人民共和国国务院总理)

Zhao Ziyang (赵紫阳) 10 September 1980-24 November 1987

Li Peng (李鹏) (acting 24 November 1987-25 March 1988); 25 March 1988-17 March 1998

Zhu Rongji (朱镕基) 17 March 1998-16 March 2003

Wen Jiabao (温家宝) 16 March 2003-(incumbent)

General Secretary of the Chinese Communist Party (中国共产党中央委员 会总书记)

Hu Yaobang (胡耀邦) 1981-16 January 1987

Zhao Ziyang (赵紫阳) 16 January 1987-23 June 1989

Since Zhao, the President has been General Secretary.

Chairman of the Central Military Commission (中央军事委员会领导)

Deng Xiaoping (邓小平) 28 June 1981-9 November 1989

Since Deng, this position has been held by the President.

Paramount Leader (党和国家最高领导人)

Deng Xiaoping (邓小平) 22 December 1978-12 October 1992

Since Deng, the position of Paramount Leader has been tied to formal office - the Presidency. 